Institute for Research on Poverty

Discussion Paper no. 1181-98

\title{
Immigration Reform and the Earnings of Latino Workers: Do Employer Sanctions Cause Discrimination?
}

\author{
Cynthia Bansak \\ Department of Economics \\ University of California, San Diego \\ E-mail: cbansak@weber.ucsd.edu \\ Steven Raphael \\ Department of Economics \\ University of California, San Diego \\ E-mail: sraphael@weber.ucsd.edu
}

December 1998

The authors thank Julian Betts, John DiNardo, Daniel Hamermesh, Harry Holzer, Lorien Rice, and Stephen Trejo for their helpful suggestions.

IRP publications (discussion papers, special reports, and the newsletter Focus) are now available on the Internet. The IRP Web site can be accessed at the following address: http://www.ssc.wisc.edu/irp/ 


\begin{abstract}
This paper investigates whether employer sanctions for hiring undocumented workers introduced by the 1986 Immigration Reform and Control Act (IRCA) adversely affected the hourly earnings of Latino workers in the southwestern United States. We exploit the staggering of the sanctions and employee verification requirements across sectors to estimate this effect. In particular, IRCA's employer-sanctions provisions were not extended to agricultural employers until 2 years after their imposition on nonagricultural employers. Hence, Latino agricultural workers provide a control group against which to compare changes in the wages of Latinos in nonagricultural employment. We find substantial pre-post IRCA declines in the hourly earnings of Latino nonagricultural workers relative to Latinos in agriculture. This pattern, however, is considerably stronger for Latino men than Latina women. We do not observe similar intersectoral shifts in relative wages among non-Latino white workers. In fact, the relative wage changes for non-Latino white workers are of the opposite sign. Finally, the pre-post IRCA relative decline in Latino nonagricultural wages reverses the pre-IRCA trend in which the relative earnings of Latino nonagricultural workers had been increasing.
\end{abstract}




\section{Immigration Reform and the Earnings of Latino Workers: Do Employer Sanctions Cause Discrimination?}

\section{INTRODUCTION}

In recent years, controlling undocumented immigration has become an issue of immediate concern to liberal democracies throughout the industrialized world. Proponents of stiff immigration controls argue that undocumented immigration creates many severe problems in receiving countries, including the generation of net fiscal deficits, the aggravation of the earnings gap between native skilled and unskilled workers, and the creation of social tensions by large inflows of foreign nationals. The imposition of sanctions on employers who knowingly hire unauthorized workers is a common policy tool intended to deter undocumented immigration. To date, several industrialized nations have legislation in place that authorizes the levying of sanctions ranging from fines to prison terms against employers of undocumented immigrants. ${ }^{1}$

One potential unintended consequence of this policy tool is that employer sanctions may result in discrimination against authorized immigrants or even against native workers who look or sound foreignborn. In the absence of a strong system of national identification, employers may use personal appearance, accent, or race and ethnicity to infer immigration status. The resulting employment discrimination may take many forms. Employers may refuse outright to hire immigrants or members of certain racial or ethnic groups. Alternatively, employers may demand that workers whom they suspect of being unauthorized work for lower wages to compensate employers for undertaking the risk of future fines.

In this paper, we estimate the extent to which employer sanctions introduced by the 1986 Immigration Reform and Control Act (IRCA) adversely affected the hourly earnings of Latino workers. To

${ }^{1}$ For discussion of employer sanctions in Canada, France, and Japan, see Kubat (1993), Miller (1994), and Morita and Sassen (1994). For a general discussion of employer sanctions in the United States, see Keeley (1993) and Perotti (1994). 
identify the effect of sanctions, we exploit the legislation's staggered imposition across sectors of the employee-verification and employer-sanctions provisions. The requirement that employers verify the immigration status of applicants went into effect in November 1986 for all nonagricultural employers, and fines for violations began being levied after a short grace period. Agricultural employers, however, were exempt from these provisions until December 1988. Hence, Latino agricultural workers provide a natural control group against which we can compare changes in the earnings of Latinos working in nonagricultural industries.

We use the Current Population Survey (CPS) Outgoing Rotation Group (ORG) files for 1983 through 1990 for the four southwestern U.S. states sharing a border with Mexico to analyze pre-post IRCA changes in the wages of Latino nonagricultural workers relative to Latinos working in agriculture. In addition, we compare these relative wage changes for Latino workers against comparable relative wage changes for non-Latino white workers. This latter "triple-difference" estimate of the employer-sanctions effect accounts for potential bias due to sector-specific shifts in labor demand or supply. Finally, we document earlier and later changes in intersectoral wage differences for Latino and non-Latino white workers to assess whether the wage developments occurring during the period bracketing IRCA's passage reflect a longer-term trend.

We find substantial pre-post IRCA declines in the hourly earnings of Latino nonagricultural workers relative to Latinos in agriculture. This pattern, however, is considerably stronger for Latino men than Latina women. We do not observe similar intersectoral shifts in relative wages among non-Latino white workers. In fact, the relative wage changes for non-Latino white workers are of the opposite sign. Finally, the pre-post IRCA relative decline in Latino nonagricultural wages reverses the pre-IRCA trend in which the relative earnings of Latino nonagricultural workers had been increasing. 


\section{IRCA AND THE EARNINGS OF LATINOS: THEORETICAL PREDICTIONS AND PAST RESEARCH}

IRCA's provisions were explicitly designed to reduce the flow of undocumented immigrants into the United States. First, the legislation increased the resources allocated to border enforcement. Second, IRCA authorized two amnesty programs that legalized long-term undocumented residents and undocumented workers who could demonstrate past labor force attachment to U.S. agriculture. ${ }^{2}$ Finally, IRCA for the first time made it illegal for employers to knowingly hire unauthorized immigrant workers and specified sanctions to be imposed against employers that violate the law.

IRCA's employee-verification provision requires that employers make a "good faith" effort to verify the work eligibility of all newly hired employees and that employers not hire workers who cannot provide the required documentation. Employers must fill out and retain an Employment Eligibility Verification form (commonly referred to as the I-9 form) for each new employee. On the form, the employer attests under penalty of perjury that he or she has reviewed acceptable documents presented by the new employee that establish the employee's identity and eligibility to work. ${ }^{3}$ Sanctions are levied against employers for violating IRCA's verification and record-keeping requirements and for knowingly employing unauthorized immigrants. Actual sanctions range from fines, varying in amount with the number

\footnotetext{
${ }^{2}$ The general amnesty program granted resident-alien status to undocumented immigrants residing in the country continuously since at least January 1, 1982. The Special Agricultural Worker (SAW) program granted legal status to undocumented aliens who could provide proof of 90 days of farm work in the U.S. in the 12 months prior to May 1, 1986. The general amnesty program represented an attempt to "wipe the slate clean" for those undocumented workers who had demonstrated a long-term commitment to the country through extended residence (Phillips and Massey 1998), while the SAW provision helped garner the political support of growers (Martin and Taylor 1988).

${ }^{3} \mathrm{~A}$ list of acceptable documents to establish identity and work eligibility is provided by the U.S. Immigration and Naturalization Service (INS) on the I-9 form.
} 
of past offenses and the number of unauthorized workers hired, to prison sentences for particularly egregious offenders (Humel-Montwieler 1987). ${ }^{4}$

The prospect that employer sanctions might contribute to discrimination against legal immigrants figured prominently both in the 15-year legislative debate preceding IRCA's passage and in the eventual form of the legislation. Of particular concern were the potential adverse effects on authorized Latino workers (Perotti 1994). Opponents of employer sanctions argued that the lack of a strong system of national identification coupled with the large number of admissible documents that workers might present would create confusion and uncertainty among employers. To hedge against the risk of being fined, employers may resort to statistical discrimination against workers from ethnic groups that are disproportionately represented among the population of undocumented workers. Given the fact that a large share of undocumented aliens are from Latin-American source countries, any unintended discrimination resulting from IRCA will disproportionately burden Latino workers. ${ }^{5}$

Several attempts have been made to assess whether employer sanctions have resulted in labor market discrimination against foreign-appearing and, in particular, Latino workers. To date, the General Accounting Office (GAO) presents the most extensive analysis of IRCA-related employment discrimination (GAO 1990). The GAO study employs several alternative strategies to estimate the pervasiveness of IRCA-related labor market discrimination, including a large, nationally representative survey of employer hiring practices in 1989, audit studies in San Diego and Chicago where paired Latino and non-Latino white

${ }^{4}$ For employment violations, the law specifies fines for the first offense of $\$ 250$ to $\$ 2,000$ for each alien involved, a per-alien fine of $\$ 2,000$ to $\$ 5,000$ for a second offense, and a per-alien fine of $\$ 3,000$ to $\$ 10,000$ for a third offense. For pattern or practice violators, the law calls for additional fines and up to 6 months in prison. Record-keeping violations result in civil fines ranging from $\$ 100$ to $\$ 1,000$.

${ }^{5}$ Several models of wage determination suggest that IRCA's employer-sanctions provision may cause a decrease in Latino earnings. First, to the extent that employers have less than perfect information about the immigration status of Latino applicants, employers may demand that all Latino applicants accept lower wages to compensate for the risk of fines. Alternatively, if a significant fraction of employers refuse to hire Latino workers, firms that will employ Latinos may take advantage of the implied reduction in the labor supply elasticities of Latino workers and pay wages that are below marginal revenue products (Black 1995; Raphael and Riker 1998). 
auditors apply for the same jobs, and an analysis of foreign-origin discrimination charges filed with the Equal Employment Opportunity Commission (EEOC) between 1979 and 1989. ${ }^{6}$ Results from the employer survey indicate that a substantial minority of employers engage in illegal discriminatory practices such as only examining the documents of applicants who are foreign-looking, or not hiring applicants with a foreign appearance or who present Puerto Rican birth certificates. Concerning the audit study, Latino members of the audit pairs were considerably more likely to be treated unfavorably in the application process than nonLatino white members, and furthermore, received relatively fewer job offers (GAO 1990; Kenney and Wissoker 1994). Analysis of EEOC complaints, however, does not indicate a post-IRCA increase in the number of discrimination complaints being filed .

Despite the GAO's conclusion that IRCA induced a substantial amount of employment discrimination against legal immigrants (GAO 1990, p. 71), the methodological design of the tests presented in the GAO report raises questions concerning the true source of the measured discriminatory practices (Lowell, Teachman, and Jing 1995). Specifically, the study presents no pre-IRCA baseline estimates against which to compare the results from the GAO's two main pieces of evidence: the employer survey and the audit studies of Chicago and San Diego. Hence, it is impossible to disentangle IRCAinduced discrimination from preference-based discrimination having nothing to do with immigration reform.

In response to this criticism, subsequent research has focused on pre-post comparisons of labor market outcomes for workers most likely to be affected by the legislation's provisions. One set of studies uses data from a series of household surveys conducted in central-Mexican, immigrant-sending

${ }^{6}$ In recognition of the potential unintended consequences of IRCA, the legislation itself included the requirement that the GAO carry out a study to evaluate whether the legislation has resulted in a pattern of widespread discrimination. Moreover, the legislation includes an explicit option for a fast-track repeal of the employer-sanctions provision conditional on the GAO findings (Lowell, Teachman, and Jing 1995). In addition, IRCA includes an antidiscrimination provision applicable to all employers with three or more workers, prohibiting discrimination on the basis of national origin or citizenship status against any U.S. citizen, legal resident alien, or refugee. The Office of Special Counsel in the Department of Justice was created to enforce this new antidiscrimination law. 
communities to compare the earnings and employment outcomes of Mexican immigrant workers stratified by the timing of their last trip to the United States (Donato, Durand, and Massey 1992; Donato and Massey 1993; Phillips and Massey 1998). These studies generally find a structural break in the mechanisms determining labor market outcomes after 1986. For example, Phillips and Massey (1998) find a large increase in the wage penalty associated with being undocumented in the post-IRCA period. Donato, Durand, and Massey (1992) find that average hours and monthly earnings of Mexican immigrants decline sharply after the passage of IRCA, while Donato and Massey (1993) find little evidence of a pre-post IRCA decline in the hourly wages of Mexican immigrants.

Using CPS data for the United States, Sorensen and Bean (1994) analyzed pre-post IRCA changes in the earnings of Mexican workers stratified by country of birth and, for immigrants, by length of time in the United States. The results from this study are mixed, indicating large effects on certain subgroups within the resident Mexican population and small or no effects for other subgroups. After adjusting for observable human capital variables, the authors find a significant pre-post IRCA decline in real hourly earnings for Mexican immigrants who had been in the country for 11+ years at the time of the survey. For more recent Mexican immigrants and native-born Mexican Americans, wages do not decrease over the period of the study.

Whereas these latter studies indicate that IRCA had a modest overall earnings effect on Latino workers, there are several reasons why one cannot draw conclusions concerning the extent of IRCAinduced discrimination from this research. To start, these before-after comparisons rely on absolute changes in earnings for the group of workers most likely to be affected by employer sanctions rather than changes relative to a group of workers unaffected by employer sanctions. ${ }^{7}$ To the extent that all other

${ }^{7}$ Sorensen and Bean (1994) do present comparisons of pre-post IRCA changes in earnings for non-Latino whites stratified by citizenship and, for immigrants, by year of entry. In their descriptive statistics presented in Table 1 of the text, there are relative declines in the earnings of Mexican workers for both native-born and nonnative-born residents as well as for all groups of Mexican immigrants. The authors, however, do not emphasize 
relevant factors in the economy that influence wages do not change over the period in question, the absence of a control group would not present a problem. However, this is an unlikely (or at least highly questionable) counterfactual given the fact that the legislation was enacted during an economic expansion and in light of the well-documented changes in the wage structure occurring during the 1980s (Levy and Murnane 1992).

Furthermore, IRCA's other provisions besides sanctions are also likely to have affected Latino wages. Hence, isolating the effect of employer sanctions requires accounting for these other IRCA-induced wage effects. Of particular importance are IRCA's two legalization programs. As of May 16, 1990, approximately 1.8 million immigrants applied for permanent-resident status under IRCA's general amnesty program; approximately 70 percent came from Mexican applicants and 13 percent from Central-American applicants. Moreover, approximately 72 percent of amnesty applications came from residents of the four border states studied here (U.S. INS 1989). To the extent that legal status provides an entryway to better employment, the increase in the proportion of the Latino population authorized to work may have increased average Latino earnings. ${ }^{8}$

Similarly, IRCA’s Special Agricultural Worker (SAW) program received approximately 1.3 million applications as of May 16, 1990, nearly 75 percent of which came from Mexican and CentralAmerican immigrants (U.S. INS 1990). The number of applications received greatly exceeded the projected size of the agricultural workforce (of approximately 300,000), leading many to speculate that the majority of applications were fraudulent and that the program resulted in new immigration into the United States

these implicit difference-in-difference calculations and do not present significance tests of these relative changes.

${ }^{8}$ Recall, general amnesty was extended to residents who could demonstrate continuous residence in the United States since at least January 1, 1982. To the extent that applications for adjustment under this program were not fraudulent, the general amnesty did not increase the size of the Latino population residing in the U.S. and, hence, did not affect the position of the aggregate Latino labor supply curve. 
(Martin and Taylor 1990). To the extent that new immigration did occur, the supply shift induced by the SAW program would decrease the wages of Latino workers.

Given the likely wage effects of the two legalization provisions, coupled with the fact that the legislation was enacted during an economic expansion, simple before-after comparisons of Latino earnings cannot isolate the discriminatory impact of employer sanctions. Doing so requires defining a control group of workers who (1) are not affected by the employer-sanctions requirements and (2) are affected by the IRCA legalization provisions in a manner similar to the effects on the implicit treatment group of workers. Below, we define a group that, we argue, meets these two criteria.

\section{EMPIRICAL METHODOLOGY AND DATA DESCRIPTION}

Our empirical strategy for isolating the effect of employer sanctions on Latino wages uses the difference in timing across sectors of the application of the IRCA employee-verification and employersanctions provisions. The timing of the extension of regulations is as follows. For nonagricultural employers, the reporting and hiring requirements apply to all workers hired after November 6, 1986. Undocumented workers hired prior to this date are not affected by the legislation. There were no inspections or fines issued during a 6-month "public information" period beginning on December 6, 1986.

In addition, for the 1-year period following the 6-month grace period, nonagricultural employers that upon inspection were found to be in violation of IRCA were issued warnings for the first offense. After the first warning, however, employers were subject to fines even if the second violation was discovered during the 1-year period.

Despite the lax enforcement during this initial phase-in, nonagricultural employers, by law, were required to complete I-9 forms for all workers and conform with IRCA's hiring requirements. Moreover, immediately after the passage of IRCA, the government made extensive efforts (including directly 
contacting two million employers) to educate employers about the legislation's reporting and hiring requirements (GAO 1990). Hence, knowledge among nonagricultural employers of the IRCA requirements, by all accounts, was widespread following the legislation's enactment. Moreover, to the extent that the legislation created confusion among employers and unnecessary discrimination against authorized foreigners and foreign-looking natives, one would expect to observe consequences during this initial phasein period.

Agricultural employers, on the other hand, were not legally required to abide by the employment and record-keeping requirements until December 1988, fully 2 years after the application of the requirements in the nonagricultural sector. During the legislative debate, growers argued that they had become particularly dependent on undocumented migrant labor. Hence, in exchange for the growers' political support, framers of IRCA included two concessions for agriculture: the SAW program discussed above and a 2-year delay in the verification and hiring requirements. ${ }^{9}$ The fresh supply of legalized farm workers and the extended grace period were intended to provide growers the necessary leeway to shift their production process toward using a predominantly legalized workforce (Martin and Taylor 1990).

The staggered imposition across sectors of the employee-verification and hiring requirements provides a natural experiment for evaluating the effect of employer sanctions on the earnings of Latino workers via a demand-side response to the sanctions. Making the assumptions that (1) Latinos working in agriculture are similar to Latinos working for nonagricultural firms, (2) wages in the nonagricultural and agricultural sectors were affected in a similar fashion by the concurrent economic expansion, and (3) Latino agricultural and nonagricultural workers were affected similarly by the legalization provisions of

${ }^{9}$ There was no initial phase-in period of sanctions for agricultural employers comparable to the initial phase-in for nonagricultural employers. An additional concession to agriculture concerned the practice of warrantless searches of fields for undocumented workers. IRCA contains a provision that restricts INS officers from entering open fields in search of undocumented workers without the "consent of the owner or without a properly executed warrant" (Humel-Montwieler 1987). 
IRCA, then an estimate of the effect of employer sanctions on the wages of Latinos working in nonagricultural jobs is given by

$$
\Delta_{\text {Latino }}^{2}=\left(W_{\text {non }}^{A}-W_{\text {non }}^{B}\right)-\left(W_{a g}^{A}-W_{a g}^{B}\right)
$$

where $W_{j}^{i}$, is the average of hourly log wages for Latino workers employed in sector $j$

(non=nonagricultural, $a g=$ agricultural $)$ in time period $i(A=$ post-IRCA, $B=$ pre-IRCA). To exploit the sectoral differences in the timing of the new regulations, the double-difference calculation given by Equation 1 must be calculated on a sample of workers restricted to the period prior to $1989 .{ }^{10}$

Undoubtedly, one can attack the three assumptions underlying this estimate of the employersanctions effect. To start, one might suspect that Latinos working in agriculture are less skilled on average than nonagricultural Latino workers. Agricultural employment does not require knowledge of English or a great deal of formal education. Hence, any estimate relying on differences in the pre-post IRCA changes in wages must account for possible differences in human capital. An alternative estimate that adjusts for differences in observable characteristics is given by estimating the following equation for the pooled sample of Latino agricultural and nonagricultural workers:

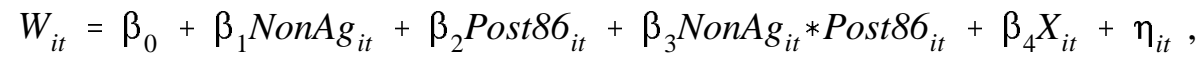

where $i$ indexes individuals and $t$ indexes time, $W_{i t}$ is the log of hourly wages, $N o n A g_{i t}$ is a dummy variable indicating a nonagricultural worker, $P$ Post $86_{i t}$ is a dummy variable indicating a wage observation recorded after 1986, $X_{i t}$ is a vector of observable demographic and skills variables, $\beta_{0}$ through $\beta_{4}$ are parameters, and $\eta_{i t}$ is a normally distributed error term. The coefficient $\beta_{3}$ on the interaction term gives the extent to which

\footnotetext{
${ }^{10}$ Technically, regulation went into effect in the agricultural sector in the last month of 1988 . However, in subsequent analysis we treat the whole year of 1988 as not being regulated. This treatment of the month of December 1988 would bias the results toward not finding significant double differences.
} 
the pre-post IRCA change in nonagricultural Latino wages differs from the comparable change in agricultural wages after controlling for the background variables included in the vector $X_{i t}$. This coefficient estimate is directly comparable to the unadjusted double-difference in Equation 1. Below, we estimate Equation 2 using a standard set of background variables and several alternative specifications.

Concerning the second assumption regarding the impact of the economic expansion across sectors, there are several reasons to suspect that agricultural and nonagricultural wages may have been affected differentially by the expansion of the mid-1980s. To the extent that growth in product demand over the relevant time period differed across sectors, the consequent sector-specific shifts in labor demand may not be of a similar magnitude. Moreover, to the extent that the labor supply elasticities faced by employers in the two sectors differ, even sector-neutral shifts in labor demand will result in different sectoral wage effects.

To address these concerns we employ a triple-difference estimator following Hamermesh and Trejo (1998). We first calculate a pre-post IRCA double-difference for non-Latino white workers (white workers, for short) comparable to that for Latino workers given by Equation 1. Next, assuming that changes in the intersectoral wage structure are similar for Latino and white workers, an estimate of the employersanctions effect that accounts for non-neutralities across sectors is given by

$$
\Delta^{3}=\Delta_{\text {Latino }}^{2}-\Delta_{\text {White }}^{2}
$$

where $\Delta_{\text {Latino }}^{2}$ is given by Equation 1, and $\Delta^{2}{ }_{\text {White }}$ is the comparable double-difference for white workers. The estimator uses the intersectoral relative wage changes for white workers as a baseline against which to compare the similar change for Latino workers. To the extent that economic growth does not affect intersectoral wage differences, $\Delta^{2}{ }_{\text {White }}$ would be equal to zero. Adjusting the triple difference for differences in observable characteristics simply requires estimating the following equation on the pooled sample of Latino and white workers: 


$$
\begin{gathered}
W_{i t}=\beta_{0}+\beta_{1} \text { NonAg }_{i t}+\beta_{2} \text { Latino }_{i t}+\beta_{3}{\text { Post } 86_{i t}+\beta_{4} \text { NonAg }_{i t} * \text { Latino }_{i t}+} \\
\beta_{5} \text { NonAg }_{i t} * \text { Post86 }_{i t}+\beta_{6} \text { Latino }_{i t} *{\text { Post } 86_{i t}}_{i t}+\beta_{7} \text { NonAg }_{i t} * \text { Latino }_{i t} * \text { Post }_{i t}+\beta_{8} X_{i t}+\eta_{i t},
\end{gathered}
$$

where Latino $_{i t}$ is a dummy variable indicating a Latino worker and all other variables are as defined above. Here, the employer-sanctions effect on the earnings of Latino nonagricultural workers is given by the coefficient $\beta_{7}$. This parameter gives the extent to which the relative change over time in Latino earnings (nonagricultural to agricultural) differs from the comparable change for non-Latino workers after adjusting for differences in the observable characteristics.

The final assumption, that Latino agricultural and nonagricultural workers were affected similarly by IRCA's legalization provisions, is probably the most difficult to address. To the extent that the proportion undocumented differed across sectors before passage of IRCA, the effect on Latino wages caused by the expansion of opportunities afforded by legal status will differ across sectors. Moreover, although the general amnesty is thought to have legalized long-term residents, the SAW program is widely believed to have resulted in increased migration into the country, especially of young Mexican males (Perotti 1994; U.S. INS 1990). Given that the SAW was explicitly tied to agriculture, one might expect that supply shifts induced by the SAW program disproportionately affected agricultural workers.

Addressing the first problem would require data on the legal status of workers before and after the enactment of IRCA. Although we do not have this information, we do observe differences in ethnic identification within the Latino population. The CPS subdivides the Latino population into Mexican American, Chicano, Mexicano, Puerto Rican, Cuban, Central or South American, and other Spanish. Cross-tabulations from the February 1994 CPS indicate that the percentage foreign-born, as well as the percentage of noncitizens, differs considerably across these categories (see Appendix Table 1). To the extent that the proportion legal also differs across these categories, and that the distribution of workers across these categories differs across sectors, a set of dummy variables indicating the specific subgroup 
provides a partial proxy for sectoral differences in the proportion of workers that had their status adjusted under the general amnesty. Concerning differential supply shifts across sectors, the SAW program most likely had a more negative impact on the wages of agricultural workers. This will impart a downward bias to our estimates of the discriminatory impacts of employer sanctions in the nonagricultural sector. Since we are unable to account for this possibility, we simply acknowledge the potential understatement.

To note a final qualification, since we observe neither the citizenship nor immigration status of workers, we are unable to determine whether our estimates of the employer-sanctions effects apply to authorized Latino workers, unauthorized Latino workers, or both. ${ }^{11}$ However, given the fact that the number of workers granted amnesty is quite close to estimates of the size of the pre-IRCA undocumented population, ${ }^{12}$ any negative wage effects associated with employer sanctions are most likely to reflect discrimination against Latinos legally authorized to work in the United States. Moreover, the stated intention of the employer-sanctions provision was to eliminate the opportunities available to undocumented immigrants, not to induce employers to extract negative compensating differentials from unauthorized laborers. To the extent that IRCA induced such behavior, the efficacy of employer sanctions within the current set of institutions needs to be reassessed.

Our principal comparisons use the ORG files from the monthly CPS for the years 1985 through

1988. In an analysis of longer-term wage trends we also use the combined monthly files for the years 1983 to 1990 . The sample includes Latino and non-Latino white wage and salary workers aged 16 to 65 with

\footnotetext{
${ }^{11}$ An additional question concerns whether undocumented immigrants even respond to CPS interviewers. To the extent that undocumented workers are missed by the CPS and that the IRCA amnesty programs pulled new respondents into the sample, the composition of the post-IRCA Latino sample may differ from the pre-IRCA Latino sample. Though it is difficult to ascertain whether CPS samples include the undocumented, this will only affect our results if the sample composition change for Latino nonagricultural workers differs from that for Latino agricultural workers. Moreover, previous research attempting to measure the size of the undocumented population generally asserts that undocumented immigrants can and do respond to the CPS (Woodrow and Passel 1990).

${ }^{12}$ Woodrow and Passel (1990) estimated the size of the undocumented population in 1986 at approximately 3.1 million, 93 percent of which was accounted for by Mexican immigrants ( 2.2 million) and immigrants from other Latin-American countries (0.7 million).
} 
observable earnings information and who were residing in the states of Arizona, California, New Mexico, or Texas at the time of the survey. An additional restriction placed on the sample comes from differences across years in the real value of the topcode on the weekly earnings variable used to construct wages. In 1983 through 1988 , the nominal topcode on weekly earnings is $\$ 999$; after 1988 the topcode increases to $\$ 1,923$. To be consistent across years, we calculate nominal topcode values for the years $1983-1987$ and 1989-1990 that equal \$999 when expressed in 1988 constant dollars. We then assign the new topcode to all observations with weekly earnings that exceed the consistent topcode value.

Our focus on the four border states is justified by several considerations. To start, Latinos of Mexican and Central-American descent constitute the overwhelming majority of Latinos in the Southwest, as well as the majority of undocumented immigrants in this region of the country (Woodrow and Passel 1990). To the extent that IRCA-induced discrimination against Latinos exists, one would expect to see the largest effects in states where the majority of Latinos are either immigrants or the descendants of immigrants from major source countries of undocumented workers. ${ }^{13}$ Second, the agricultural sector in these four states is a relatively large employer of Latino labor; hence, the sample should generate sufficient observations to estimate the models outlined above.

Throughout the paper, the dependent variable of interest is the log of the real value (the nominal wage deflated by the CPI) of hourly wages. Following DiNardo, Fortin, and Lemieux (1996), we weight all the cross-tabulations and regressions below by an hours-adjusted weight equal to the CPS earnings weight multiplied by the weekly hours of work for each observation. This weighting scheme essentially places more weight on workers with high weekly hours. Given that we are interested in estimating changes in the

\footnotetext{
${ }^{13}$ Latinos of Mexican descent make up over three-quarters of the Latino population in these four border states. In comparison to other states with large Latino communities, cross-tabs from the combined ORG 1986 files for New York and Florida show that 4 and 7 percent, respectively, of the Latino population in these states is of Mexican descent. In New York, approximately half of the Latino population is Puerto Rican, while in Florida over half of the Latino population is Cuban. Given the fact that there are no visa requirements for Puerto Ricans and given that Cuban immigrants are generally authorized, one would not expect sizable effects of IRCA on Latino earnings in these states.
} 
average price paid for an hour of labor defined by ethnicity and sector, we feel that this weighting strategy more accurately measures the effect of employer sanctions. To be complete, we present parallel unweighted estimates of the employer-sanctions effect in Appendix Table 2.

Table 1 presents mean values using the 1985 to 1988 sample for the dependent and explanatory variables of interest for Latino and non-Latino white workers overall, and within ethnic groups, by sector of employment. For Latino workers, there are several substantial differences between agricultural and nonagricultural workers. Latinos working in agriculture are considerably less educated, have more potential work experience (defined as age-education-6), are less likely to be female, more likely to reside in California, and have considerably lower hourly earnings. In addition, a much greater proportion of Latino agricultural workers self-identify as being "Mexicano" (Spanish for Mexican), while a smaller proportion self-identify as Mexican American. Hence, these cross-tabs indicate that immigrants, and possibly undocumented immigrants, account for a larger share of Latino workers in agriculture than in nonagriculture. There are similar intersectoral differences among non-Latino white workers, with a substantial hourly earnings differential similar in magnitude to that observed for Latino workers and a relatively smaller difference in educational attainment. Finally, Latino workers overall earn considerably less per hour than non-Latino white workers, are less educated, are less likely to be female, and are more likely to work in agriculture.

\section{4. $\quad$ EMPIRICAL RESULTS}

Table 2 presents three sets of estimates of the employer-sanctions effect corresponding to Equations 1 and 3. The first three rows (panel A) present calculations for workers pooled across gender, the second three rows (panel B) present estimates for males, and the final three rows (panel C) present estimates for females. Within each panel, two $3 \times 3$ matrices of figures provide separate estimates for Latino 
TABLE 1 Mean Values for the Dependent and Explanatory Variables,
by Ethnicity and Sector of Employment

\begin{tabular}{|c|c|c|c|c|c|c|}
\hline & \multicolumn{3}{|c|}{ Latino } & \multicolumn{3}{|c|}{ Non-Latino White } \\
\hline & All & NonAg & $\mathrm{Ag}$ & All & NonAg & $\mathrm{Ag}$ \\
\hline Log real wages & 1.76 & 1.78 & 1.40 & 2.13 & 2.14 & 1.68 \\
\hline Education & 10.44 & 10.70 & 6.41 & 13.72 & 13.73 & 12.46 \\
\hline Experience & 16.87 & 16.62 & 20.78 & 16.69 & 16.71 & 14.49 \\
\hline Married & .64 & .64 & .67 & .62 & .62 & .53 \\
\hline Veteran & .09 & .10 & .02 & .20 & .20 & .14 \\
\hline Female & .36 & .37 & .10 & .43 & .43 & .25 \\
\hline Agriculture & .06 & - & - & .01 & - & 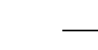 \\
\hline California & .56 & .56 & .65 & .55 & .55 & .56 \\
\hline Texas & .34 & .35 & .24 & .35 & .35 & .32 \\
\hline Arizona & .05 & .05 & .08 & .08 & .08 & .07 \\
\hline New Mexico & .04 & .04 & .03 & .02 & .02 & .04 \\
\hline Mexican American & .48 & .49 & .30 & - & - & 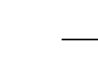 \\
\hline Chicano & .01 & .01 & .01 & - & - & - \\
\hline Mexicano & .35 & .33 & .64 & 一 & - & - \\
\hline Puerto Rican & .02 & .02 & .00 & - & - & - \\
\hline Cuban & .01 & .01 & .00 & - & - & - \\
\hline Central/South American & .08 & .08 & .03 & - & - & - \\
\hline Other & .06 & .06 & .01 & - & - & - \\
\hline $\mathrm{N}$ & 20,410 & 19,428 & 982 & 64,721 & 64,004 & 717 \\
\hline
\end{tabular}

Notes: The sample is drawn from the combined CPS ORG files for 1985 through 1988. The sample is restricted to wage and salary workers between 16 and 65 years old who are either Latino or non-Latino white and reside in one of the four southwestern states that share a border with Mexico. 
TABLE 2

Unadjusted Double-Difference and Triple-Difference Estimates of the Effects of Employer Sanctions

\begin{tabular}{|c|c|c|c|c|c|c|c|c|}
\hline & & \multicolumn{3}{|c|}{ Latino } & \multicolumn{3}{|c|}{ Non-Latino White } & \multirow[b]{2}{*}{$\Delta^{3}$} \\
\hline & & NonAg & $\mathrm{Ag}$ & $\Delta($ NonAg-Ag $)$ & NonAg & $\mathrm{Ag}$ & $\Delta($ Non $A g-A g)$ & \\
\hline \multirow[t]{4}{*}{ Panel A. } & All & & & & & & & \\
\hline & $85 / 86$ & $\begin{array}{l}1.797 \\
(.005)\end{array}$ & $\begin{array}{l}1.364 \\
(.019)\end{array}$ & $\begin{array}{c}.432 \\
(.021)\end{array}$ & $\begin{array}{c}2.138 \\
(.003)\end{array}$ & $\begin{array}{l}1.745 \\
(.026)\end{array}$ & $\begin{array}{c}.393 \\
(.026)\end{array}$ & - \\
\hline & $87 / 88$ & $\begin{array}{l}1.772 \\
(.005)\end{array}$ & $\begin{array}{l}1.432 \\
(.016)\end{array}$ & $\begin{array}{c}.340 \\
(.021)\end{array}$ & $\begin{array}{c}2.137 \\
(.003)\end{array}$ & $\begin{array}{l}1.597 \\
(.030)\end{array}$ & $\begin{array}{c}.540 \\
(.030)\end{array}$ & - \\
\hline & $\Delta(87 / 88-85 / 86)$ & $\begin{array}{l}-.025 \\
(.007)\end{array}$ & $\begin{array}{c}.067 \\
(.025)\end{array}$ & $\begin{array}{l}-.092 \\
(.030)\end{array}$ & $\begin{array}{l}-.001 \\
(.004)\end{array}$ & $\begin{array}{l}-.148 \\
(.040)\end{array}$ & $\begin{array}{l}.148 \\
(.040)\end{array}$ & $\begin{array}{l}-.240 \\
(.050)\end{array}$ \\
\hline \multirow[t]{4}{*}{ Panel B. } & Males & & & & & & & \\
\hline & $85 / 86$ & $\begin{array}{l}1.883 \\
(.007)\end{array}$ & $\begin{array}{l}1.355 \\
(.021)\end{array}$ & $\begin{array}{c}.528 \\
(.023)\end{array}$ & $\begin{array}{c}2.283 \\
(.004)\end{array}$ & $\begin{array}{l}1.729 \\
(.032)\end{array}$ & $\begin{array}{c}.554 \\
(.030)\end{array}$ & - \\
\hline & $87 / 88$ & $\begin{array}{l}1.852 \\
(.007)\end{array}$ & $\begin{array}{l}1.430 \\
(.016)\end{array}$ & $\begin{array}{c}.422 \\
(.023)\end{array}$ & $\begin{array}{c}2.274 \\
(.004)\end{array}$ & $\begin{array}{l}1.634 \\
(.037)\end{array}$ & $\begin{array}{c}.640 \\
(.036)\end{array}$ & - \\
\hline & $\Delta(87 / 88-85 / 86)$ & $\begin{array}{l}-.031 \\
(.010)\end{array}$ & $\begin{array}{c}.075 \\
(.027)\end{array}$ & $\begin{array}{l}-.106 \\
(.033)\end{array}$ & $\begin{array}{l}-.009 \\
(.006)\end{array}$ & $\begin{array}{l}-.095 \\
(.049)\end{array}$ & $\begin{array}{c}.086 \\
(.046)\end{array}$ & $\begin{array}{l}-.192 \\
(.056)\end{array}$ \\
\hline \multirow[t]{4}{*}{ Panel C. } & Females & & & & & & & \\
\hline & $85 / 86$ & $\begin{array}{l}1.649 \\
(.008)\end{array}$ & $\begin{array}{l}1.439 \\
(.045)\end{array}$ & $\begin{array}{c}.210 \\
(.054)\end{array}$ & $\begin{array}{l}1.946 \\
(.004)\end{array}$ & $\begin{array}{l}1.798 \\
(.040)\end{array}$ & $\begin{array}{c}.148 \\
(.049)\end{array}$ & - \\
\hline & $87 / 88$ & $\begin{array}{l}1.641 \\
(.008)\end{array}$ & $\begin{array}{l}1.453 \\
(.051)\end{array}$ & $\begin{array}{c}.188 \\
(.061)\end{array}$ & $\begin{array}{l}1.961 \\
(.004)\end{array}$ & $\begin{array}{l}1.502 \\
(.048)\end{array}$ & $\begin{array}{c}.459 \\
(.052)\end{array}$ & - \\
\hline & $\Delta(87 / 88-85 / 86)$ & $\begin{array}{l}-.008 \\
(.011)\end{array}$ & $\begin{array}{c}.014 \\
(.068)\end{array}$ & $\begin{array}{l}-.022 \\
(.081)\end{array}$ & $\begin{array}{c}.015 \\
(.006)\end{array}$ & $\begin{array}{l}-.295 \\
(.062)\end{array}$ & $\begin{array}{c}.310 \\
(.071)\end{array}$ & $\begin{array}{l}-.333 \\
(.110)\end{array}$ \\
\hline
\end{tabular}

Note: Standard errors are in parentheses. 
workers (the first three columns) and non-Latino white workers (the second three columns). Within each of these matrices, mean hourly log wages are calculated for the pre-IRCA period (1985/1986) and the postIRCA period (1987/1988) by sector of employment, with the third row giving post-pre IRCA differences and the third column giving the nonagricultural wage premium. The figure in the lower right-hand corner of each of these submatrices gives the unadjusted double-difference estimator from Equation 1. The final column of the table present the unadjusted triple-difference estimator, for all workers and separately by gender, from Equation 3. Standard errors for the point estimates are presented in parentheses.

Starting with the results for Latino workers, all three double-difference estimates show that the earnings of Latino nonagricultural workers declined relative to the earnings of Latinos in agriculture over the period when employer sanctions were introduced in the nonagricultural sector. When Latino workers are pooled across gender, the difference between nonagricultural and agricultural workers in the post-pre IRCA changes in log wages is -.092 , a near 10 percent decrease in the relative earnings of nonagricultural workers. When analyzed separately by gender, however, changes in relative earnings are considerably larger for Latino men $(-.106)$ than Latina women $(-.022)$. Moreover, while the double-difference estimates are significant at 1 percent for the pooled sample and for males, the estimate for females is not significant.

Turning to the comparable changes for non-Latino white workers, the double-difference estimates are positive. For both the pooled sample and gender-specific results, the earnings of nonagricultural white workers increase relative to the earnings of whites working in agriculture over the period when employer sanctions are introduced in the nonagricultural sector. These relative changes are fairly large in all comparisons (.148 for the pooled sample, .086 for males, and .310 for females), significant at 1 percent for the total sample and for white females, and significant at 10 percent for white males.

The triple-difference results in the final column of Table 2 give the difference between the doubledifference estimates in column 3 for Latino workers and the comparable figure for white workers in column 6. Recall, if we assume that the intersectoral wage changes for white workers would have applied 
to Latino workers in the absence of IRCA, this triple-difference provides an alternative estimate of the employer-sanctions effect that nets out intersector shifts in labor supply and demand. The triple-difference estimates are all large, negative, and significant at 1 percent, indicating substantial declines in the hourly earnings of Latino nonagricultural workers. Hence, the first-pass results in Table 2 are consistent with the argument that employer sanctions adversely affect the earnings of Latino workers.

One possible problem with the results in Table 2 concerns the time periods used to bracket the legislative change. In these unadjusted results, we pool observations over 2-year periods to maximize the cell sizes (especially for agricultural workers) and improve the precision of our double- and tripledifference estimates. Nonetheless, this aggregation may bias the results for a host of reasons that must be addressed. To start, our base time period includes the months immediately preceding the enactment and enforcement of IRCA's provisions. To the extent that employers, in anticipation of the legislation, altered their behavior prior to the application of the law's specific provisions, our time frame will understate the possible adverse earnings effect of employer sanctions. ${ }^{14}$ Another problem concerns state legislative changes in our post-IRCA time period. In particular, California unilaterally increased the state minimum wage above the federal floor on July 1, 1988 (Card and Krueger 1995). The potential bias to our estimates of the effects of employer sanctions depends on the percentage of Latino workers in each sector that were affected by the increase (i.e., were in the range for a raise and working for an employer that complied) and could go in either direction.

To investigate the sensitivity of our results to changes in the time periods chosen, Appendix Table 3 presents tabulations comparable to those in Table 2 for all workers using alternative single-year pre- and

\footnotetext{
${ }^{14}$ In a similar vein, given the fact that undocumented immigrants hired prior to November 1986 are "grandfathered" in, and the somewhat lax enforcement during the first year and a half, one might argue that the focus on the post-IRCA period of 1987-1988 may not capture the complete effect of the law on Latino earnings. However, since employer sanctions went into effect for agriculture in 1988, our present methodological framework is restricted to this time period.
} 
post-IRCA time periods. ${ }^{15}$ The table provides results comparing 1986 to 1987,1986 to 1988,1985 to 1987, and 1985 to 1988. Looking first at the 1986/1987 and 1986/1988 comparisons, the double-difference estimates for Latino workers are comparable in size, significant at 1 percent, and statistically indistinguishable from one another (-.108 for the 1986/1987 comparison and - .147 for the $1986 / 1988$ comparison). In light of the fact that the California minimum wage did not increase until the middle of 1988, these results indicate that minimum wage changes are not driving the relative decline in Latino nonagricultural earnings observed in Table $2 .^{16}$

For the other comparisons, the patterns generally conform to the findings of Table 2, although the standard errors on the double- and triple-difference estimates are considerably larger than those calculated with the 2-year periods. The measured decline in the relative earnings of Latino nonagricultural workers is significant at 6 percent and moderate (-.076) for the 1985/1988 comparison, and small and insignificant for the 1985/1987 comparison. Again the relative wage changes for non-Latino white workers are of the opposite sign in all comparisons and significant in two of the comparisons. Moreover, all of the tripledifference estimates indicate a negative employer-sanctions effect on Latino earnings. Hence, for the remainder of this section we will focus on the time periods used in constructing Table 2.

Although the unadjusted results are consistent with a negative employer-sanctions effect, the basic descriptive statistics in Table 1 indicate substantial differences in observable human capital between Latino workers across sectors, as well as inter-ethnic differences, that may explain these patterns. To account for this possibility, Table 3 presents results from log-wage regressions corresponding to the model in Equation 2 using the sample of Latino workers. Recall, the coefficient on the interaction term between the dummy

\footnotetext{
${ }^{15}$ The gender-specific results yield larger relative declines for males than females (as found in Table 2) and yield similar temporal patterns to those in Appendix Table 3.

${ }^{16}$ Furthermore, only California observations from the July through December 1988 ORG files-fewer than 10 percent of the observations in the pooled 1987/1988 cell — would have been affected by the minimum wage increase.
} 
TABLE 3

Adjusted Double-Difference Estimates of Employer Sanctions from Log-Wage Equations for Latino Workers

\begin{tabular}{|c|c|c|c|c|c|c|c|c|c|}
\hline & \multicolumn{3}{|c|}{ All Workers } & \multicolumn{3}{|c|}{ Males } & \multicolumn{3}{|c|}{ Females } \\
\hline & $(1)$ & $(2)$ & (3) & $(4)$ & $(5)$ & $(6)$ & (7) & $(8)$ & (9) \\
\hline NonAg & $\begin{array}{c}.256 \\
(.018)\end{array}$ & $\begin{array}{l}-.045 \\
(.121)\end{array}$ & $\begin{array}{l}-.053 \\
(.121)\end{array}$ & $\begin{array}{c}.317 \\
(.020)\end{array}$ & $\begin{array}{l}-.010 \\
(.134)\end{array}$ & $\begin{array}{l}-.019 \\
(.134)\end{array}$ & $\begin{array}{l}-.029 \\
(.048)\end{array}$ & $\begin{array}{l}-.602 \\
(.392)\end{array}$ & $\begin{array}{l}-.601 \\
(.392)\end{array}$ \\
\hline Post-IRCA & $\begin{array}{c}.036 \\
(.024)\end{array}$ & $\begin{array}{c}.036 \\
(.024)\end{array}$ & $\begin{array}{c}.058 \\
(.032)\end{array}$ & $\begin{array}{c}.051 \\
(.026)\end{array}$ & $\begin{array}{c}.046 \\
(.026)\end{array}$ & $\begin{array}{c}.070 \\
(.037)\end{array}$ & $\begin{array}{l}-.019 \\
(.068)\end{array}$ & $\begin{array}{l}-.078 \\
(.072)\end{array}$ & $\begin{array}{l}-.064 \\
(.079)\end{array}$ \\
\hline NonAg*Post-IRCA & $\begin{array}{l}-.060 \\
(.024)\end{array}$ & $\begin{array}{l}-.060 \\
(.025)\end{array}$ & $\begin{array}{l}-.050 \\
(.026)\end{array}$ & $\begin{array}{l}-.084 \\
(.027)\end{array}$ & $\begin{array}{l}-.079 \\
(.027)\end{array}$ & $\begin{array}{l}-.068 \\
(.028)\end{array}$ & $\begin{array}{c}.009 \\
(.068)\end{array}$ & $\begin{array}{c}.067 \\
(.072)\end{array}$ & $\begin{array}{c}.076 \\
(.073)\end{array}$ \\
\hline Mexican American & $\begin{array}{l}-.065 \\
(.011)\end{array}$ & $\begin{array}{l}-.079 \\
(.089)\end{array}$ & $\begin{array}{l}-.080 \\
(.088)\end{array}$ & $\begin{array}{l}-.063 \\
(.014)\end{array}$ & $\begin{array}{l}-.008 \\
(.102)\end{array}$ & $\begin{array}{l}-.009 \\
(.102)\end{array}$ & $\begin{array}{l}-.072 \\
(.016)\end{array}$ & $\begin{array}{l}-.395 \\
(.194)\end{array}$ & $\begin{array}{l}-.397 \\
(.194)\end{array}$ \\
\hline Mexicano & $\begin{array}{l}-.150 \\
(.022)\end{array}$ & $\begin{array}{l}-.225 \\
(.090)\end{array}$ & $\begin{array}{l}-.226 \\
(.090)\end{array}$ & $\begin{array}{l}-.154 \\
(.016)\end{array}$ & $\begin{array}{l}-.170 \\
(.103)\end{array}$ & $\begin{array}{l}-.171 \\
(.103)\end{array}$ & $\begin{array}{l}-.145 \\
(.018)\end{array}$ & $\begin{array}{l}-.443 \\
(.199)\end{array}$ & $\begin{array}{l}-.444 \\
(.199)\end{array}$ \\
\hline Central/South American & $\begin{array}{l}-.211 \\
(.014)\end{array}$ & $\begin{array}{l}-.259 \\
(.113)\end{array}$ & $\begin{array}{l}-.260 \\
(.112)\end{array}$ & $\begin{array}{l}-.203 \\
(.020)\end{array}$ & $\begin{array}{l}-.192 \\
(.125)\end{array}$ & $\begin{array}{l}-.192 \\
(.125)\end{array}$ & $\begin{array}{l}-.214 \\
(.022)\end{array}$ & $\begin{array}{r}-1.879 \\
(.847)\end{array}$ & $\begin{array}{r}-1.896 \\
(.847)\end{array}$ \\
\hline Interactions with NonAg ${ }^{a}$ & No & Yes & Yes & No & Yes & Yes & No & Yes & Yes \\
\hline Interactions with Post-IRCA ${ }^{b}$ & No & No & Yes & No & No & Yes & No & No & Yes \\
\hline $\mathrm{R}^{2}$ & .346 & .351 & .351 & .358 & .363 & .364 & .299 & .302 & .303 \\
\hline $\mathrm{N}$ & 20,410 & 20,410 & 20,410 & 12,074 & 12,074 & 12,074 & 8,336 & 8,336 & 8,336 \\
\hline
\end{tabular}

Notes: Standard errors are in parentheses. All regressions control for education; experience; experience squared; dummies for married, veteran, and female (where appropriate); and three state dummy variables.

${ }^{a}$ These regressions include a complete set of interactions between the control variables and the nonagricultural dummy variables.

${ }^{b}$ These regressions include interactions between education, experience, and experience squared with the post-IRCA dummy variable. 
indicating a nonagricultural worker and a dummy variable indicating a post-IRCA observation gives the double-difference estimate after controlling for variables included in the vector $X_{i t}$. For the sample of workers pooled across genders and for males and females separately, the table presents estimation results from three model specifications: (1) a regression including all of the variables listed in Table 1 plus experience squared, (2) a regression on everything in specification 1 plus a full set of interaction terms between the explanatory variables and the nonagricultural dummy variable, and (3) a regression on all variables in specification 2 plus interaction terms between education, experience, and experience squared and the dummy variable indicating a post-IRCA observation. We include results interacting all independent variables with agriculture to rule out the possibility that any negative relative change in earnings is being driven by differences in the wage structure across sectors. Including the interactions between the traditional human capital variables and the post-IRCA dummy essentially allows for changes over time in the returns to education and experience. Accounting for this possibility is particularly important, considering the welldocumented changes in the returns to education and experience occurring during the 1980s (Freeman and Katz 1994).

For each regression, we present the coefficient estimates on the post-IRCA dummy, the nonagricultural dummy, and the interaction term between the two dummy variables. We also present the results showing the relative earnings differentials among Latinos according to their self-identified Latino ethnic subgroups. The remainder of the output is suppressed to conserve space. The results from the suppressed output strongly parallel the standard log-wage earnings results found in the literature.

For the pooled sample, controlling for observable characteristics explains part of the negative double-difference observed in the unadjusted data. Hence, while the unadjusted relative decline in Latino nonagricultural earnings from Table 2 is -.092 , the double-difference estimates from the first three columns of Table 3 range from - .050 to -.060 . In all three specifications, the coefficients on the interaction term "NonAg*Post-IRCA" are significant at 5 percent. Again, the sanctions effects are largest 
for male Latino workers; all are significant at the 1 percent level and indicate relative declines in the earnings of nonagricultural workers on the order of 7 to 9 percent. For females, there are no significant changes in the intersectoral earnings structure. The estimates for women, however, are imprecise, reflecting the low number of observations of Latina women in agriculture. Hence, the adjusted double-difference results presented in Table 3 confirm the unadjusted results presented earlier. ${ }^{17}$

Finally, Table 4 presents log-wage regression results using the pooled sample of Latino and nonLatino white workers to calculate the triple-difference estimator of the employer-sanctions earnings effect after controlling for background characteristics. For all workers, and for workers by gender, the table presents the coefficient estimates corresponding to the coefficient, $\beta_{7}$, on the triple-interaction term in Equation 4. Again, this coefficient is directly comparable to the triple-difference described in Equation 3 and calculated in the final column of Table 2. Estimates are reported for five model specifications that are listed in the notes of the table. For the most part, these specifications include the variables listed in Table 1 and various sets of interactions between this set of variables, a dummy variable indicating a Latino worker, a nonagricultural dummy, and the post-IRCA dummy.

The results from this exercise are uniform across specifications and subsamples. The tripledifference estimates from each regression are large, negative, and significant at 1 percent in all models. The triple-difference estimates of the employer-sanctions effect considerably exceed the double-difference estimates from Tables 2 and 3. These large differences may be due in part to the rather small number of observations of white (especially white female) agricultural workers and the consequently large measurement error in our estimate of changes in the intersectoral wage structure among white workers.

\footnotetext{
${ }^{17}$ The unweighted results provided in Appendix Table 2 for the double-difference estimates basically parallel the results from Tables 2 and 3. The unweighted double-difference estimates are slightly smaller than the weighted estimates (for example, unweighted and weighted estimates of the unadjusted double-difference of -.074 and -.092 for all workers and -.088 and -.106 for male workers). These estimates are for the most part statistically significant for the overall sample and for males, and insignificant for females.
} 
TABLE 4

\section{Triple-Difference Estimates of the Employer-Sanctions Earnings Effects after Adjusting for Background Characteristics}

\begin{tabular}{llll}
\hline & All Workers & Males & Females \\
\hline Unadjusted (from Table 2) & -.240 & -.192 & -.333 \\
& $(.050)$ & $(.056)$ & $(.110)$ \\
Specification 1 & -.208 & -.192 & -.306 \\
& $(.041)$ & $(.046)$ & $(.094)$ \\
Specification 2 & -.208 & & -.260 \\
& $(.041)$ & -.179 & $(.096)$ \\
Specification 3 & & $(.047)$ & -.293 \\
& -.214 & -.195 & $(.094)$ \\
Specification 4 & $(.040)$ & $(.046)$ & -.255 \\
& & & $(.096)$ \\
Specification 5 & -.213 & -.182 & -.262 \\
& $(.041)$ & $(.047)$ & $(.096)$ \\
\hline
\end{tabular}

Notes: Standard errors are in parentheses. The figures are the estimates of the coefficient on the tripleinteraction term in Equation 4 in the text. All specifications include a constant term, dummy variables for nonagricultural worker, post-IRCA, Latino, and all of the two-way interactions between the three variables. In addition, the five specifications include the following additional variables:

Specification 1: education; experience; experience squared; dummies for female, married, and veteran; and three state dummy variables.

Specification 2: specification 1 plus a complete set of interactions with the nonagricultural dummy.

Specification 3: specification 1 plus a complete set of interactions with the Latino dummy.

Specification 4: specification 1 plus two complete sets of interactions with the Latino and nonagricultural dummy variables.

Specification 5: specification 4 plus interactions between the post-IRCA dummy and education and experience. 
Nonetheless, at the least, the triple-difference estimates indicate that the change in the relative wages of Latino workers occurring during the period surrounding IRCA's passage differs significantly from the comparable change observed among white workers. Hence, these results indicate that sector-specific shifts in demand or supply are not driving our results. ${ }^{18}$

In summary, changes in relative wages over the period bracketing IRCA's implementation are consistent with the contention that employer sanctions cause discrimination against Latino workers. We find substantial declines in the earnings of Latinos in sectors affected by the legislation relative to Latinos in a sector that is unaffected. Moreover, we do not observe similar changes in the intersectoral wage structure for non-Latino white workers, a group for whom employer sanctions should not have had a large effect.

\section{CONTINUATION OF A TREND?}

Although the results from the previous section indicate potentially sizable negative effects of employer sanctions on the earnings of Latino workers, one may alternatively interpret these patterns as reflecting longer-term shifts in relative skills endowments. The flow of immigrants into the United States during the 1980s was large and concentrated in a few states, two of which (California and Texas) are represented in our sample. Moreover, there is evidence that the relative skills of immigrants from LatinAmerican source countries, relative to native-born workers, have declined in the recent past (Borjas 1994).

Because the principal empirical comparison in our tests for an employer-sanctions effect concerns relative wage changes within the Latino population, we feel that the basic double-difference results presented above are robust to this criticism. Nonetheless, the change in the relative wage structure for Latinos may itself be driven by longer-term trends. To investigate this possibility, Table 5 presents

\footnotetext{
${ }^{18}$ Again, the unweighted triple-difference results presented in Appendix Table 2 are quite close to the weighted results in Table 4.
} 
tabulations showing pre-IRCA and post-IRCA shifts in relative wages comparable to the analysis presented above. The table provides mean log wages by ethnicity and sector of employment for the periods 1983/1984, 1985/1986, 1987/1988, and 1989/1990, as well as double- and triple-difference calculations comparable to those in Table 2 for the two pre-IRCA periods, the two periods bracketing the legislation, and the two post-IRCA periods. Here we only present the results for the sample of workers pooled across genders to conserve space. The gender-specific results for these alternative time periods tell a similar story. Looking first at the double-difference estimates for Latino workers given in the third column and last three rows of Table 5, we see a statistically significant increase in the relative wages of Latino nonagricultural workers (.078) over the two pre-IRCA periods, followed by a decline in relative wages (-.092, reproduced from Table 2$)$ over the two periods surrounding the legislation, and finally a small and insignificant increase in the relative wages (.012) for the post-IRCA periods. Note, the periods used for the latter double-difference estimate brackets the imposition of employer sanctions and employee-verification requirements on agricultural employers. Looking at the components of these relative changes, Latino nonagricultural earnings are declining over the entire period. However, the absolute decline in Latino nonagricultural earnings is larger for the period bracketing IRCA's passage $(-.025)$ than the declines observed for both the two pre-IRCA periods $(-.007)$ and the two post-IRCA periods $(-.016)$.

Concerning the double-difference estimates for non-Latino white workers, we observe the mirror image, with the relative wages of nonagricultural workers declining before IRCA, increasing for the prepost period, and then declining over the two post-IRCA periods. Moreover, the triple-difference estimates show relative declines for Latino nonagricultural workers for the periods surrounding the passage of the legislation only. Hence, the relative wage changes between the periods surrounding IRCA's passage, rather than reflecting longer-term trends, appear to be a break from a trend reflected in both the two pre-IRCA periods and the two post-IRCA periods. 


\section{TABLE 5}

Unadjusted Double-Difference and Triple-Difference Estimates of the Effects of Employer Sanctions, All Workers

\begin{tabular}{|c|c|c|c|c|c|c|c|}
\hline & \multicolumn{3}{|c|}{ Latino } & \multicolumn{3}{|c|}{ Non-Latino White } & \multirow[b]{2}{*}{$\Delta^{3}$} \\
\hline & NonAg & $\mathrm{Ag}$ & $\Delta($ NonAg-Ag) & NonAg & $\mathrm{Ag}$ & $\Delta($ Non $A g-A g)$ & \\
\hline $83 / 84$ & $\begin{array}{l}1.804 \\
(.005)\end{array}$ & $\begin{array}{l}1.449 \\
(.014)\end{array}$ & $\begin{array}{c}.356 \\
(.018)\end{array}$ & $\begin{array}{c}2.103 \\
(.003)\end{array}$ & $\begin{array}{l}1.677 \\
(.022)\end{array}$ & $\begin{array}{c}.426 \\
(.023)\end{array}$ & 一 \\
\hline $85 / 86$ & $\begin{array}{l}1.797 \\
(.005)\end{array}$ & $\begin{array}{l}1.364 \\
(.019)\end{array}$ & $\begin{array}{c}.432 \\
(.021)\end{array}$ & $\begin{array}{l}2.138 \\
(.003)\end{array}$ & $\begin{array}{l}1.745 \\
(.026)\end{array}$ & $\begin{array}{c}.393 \\
(.026)\end{array}$ & - \\
\hline $87 / 88$ & $\begin{array}{l}1.772 \\
(.005)\end{array}$ & $\begin{array}{l}1.432 \\
(.016)\end{array}$ & $\begin{array}{c}.340 \\
(.021)\end{array}$ & $\begin{array}{c}2.137 \\
(.003)\end{array}$ & $\begin{array}{l}1.597 \\
(.030)\end{array}$ & $\begin{array}{c}.540 \\
(.030)\end{array}$ & - \\
\hline $89 / 90$ & $\begin{array}{l}1.756 \\
(.005)\end{array}$ & $\begin{array}{l}1.404 \\
(.014)\end{array}$ & $\begin{array}{c}.352 \\
(.018)\end{array}$ & $\begin{array}{l}2.126 \\
(.003)\end{array}$ & $\begin{array}{l}1.696 \\
(.026)\end{array}$ & $\begin{array}{c}.430 \\
(.029)\end{array}$ & - \\
\hline$\Delta(85 / 86-83 / 84)$ & $\begin{array}{l}-.007 \\
(.007)\end{array}$ & $\begin{array}{l}-.085 \\
(.024)\end{array}$ & $\begin{array}{c}.078 \\
(.027)\end{array}$ & $\begin{array}{c}.035 \\
(.004)\end{array}$ & $\begin{array}{c}.068 \\
(.034)\end{array}$ & $\begin{array}{l}-.033 \\
(.034)\end{array}$ & $\begin{array}{c}.111 \\
(.045)\end{array}$ \\
\hline$\Delta(87 / 88-85 / 86)$ & $\begin{array}{l}-.025 \\
(.007)\end{array}$ & $\begin{array}{c}.067 \\
(.025)\end{array}$ & $\begin{array}{l}-.092 \\
(.030)\end{array}$ & $\begin{array}{l}-.001 \\
(.004)\end{array}$ & $\begin{array}{l}-.148 \\
(.040)\end{array}$ & $\begin{array}{c}.148 \\
(.040)\end{array}$ & $\begin{array}{c}-.240 \\
(.050)\end{array}$ \\
\hline$\Delta(89 / 90-87 / 88)$ & $\begin{array}{l}-.016 \\
(.007)\end{array}$ & $\begin{array}{l}-.029 \\
(.021)\end{array}$ & $\begin{array}{c}.012 \\
(.028)\end{array}$ & $\begin{array}{l}-.011 \\
(.004)\end{array}$ & $\begin{array}{c}.099 \\
(.040)\end{array}$ & $\begin{array}{l}-.111 \\
(.042)\end{array}$ & $\begin{array}{c}.123 \\
(.051)\end{array}$ \\
\hline
\end{tabular}

Note: Standard errors are in parentheses. 
To more completely explore these patterns, Table 6 presents adjusted double-difference and tripledifference estimates of relative wage changes from log-wage regressions that parallel the specifications presented in Tables 3 and 4 . The first column gives the relevant coefficient estimates for the 1985/1986-1983/1984 comparison, the second column reproduces the coefficient estimates for the pre-post IRCA change from Tables 3 and 4, and the third column presents the relevant coefficients for the 1989/1990-1987/1988 comparison. In general, the patterns observed in Table 5 hold up after controlling for observable characteristics. For the two pre-IRCA periods, the double-difference estimates indicate statistically significant relative increases in the wages of nonagricultural Latino workers in all specification with the exception of specification 3, where the small measured increase is not significant. In addition, all the triple-difference coefficients are positive, and most are significant at 5 percent. The results for the two post-IRCA periods adjusted for observable characteristics parallel the unadjusted results, with doubledifference estimates that are small, positive, and insignificant, and sizable positive and significant tripledifference estimates. Hence, the evidence in Tables 5 and 6 does not indicate that the changes in the relative wage structure surrounding the immigration reform legislation are driven by longer-term trends.

\section{CONCLUSION}

The changes documented above in the relative wage structure of the southwestern border states are consistent with a negative effect of employer sanctions on the average hourly earnings of Latino workers. Wages in the nonagricultural sector decline relative to wages in agriculture over the period within which employer-sanctions and employee-verification requirements are imposed on the former sector only. Over the same period, the comparable relative change for non-Latino white workers, a group least likely to be affected by IRCA-induced discrimination, reveals an increase in the wages of nonagricultural workers. Moreover, the relative wage decline observed for Latinos during the period within which IRCA was 
TABLE 6

Double-Difference and Triple-Difference Estimates of Change in Relative Earnings of Latino Nonagricultural Workers

\begin{tabular}{|c|c|c|c|}
\hline & $\Delta(85 / 86-83 / 84)$ & $\Delta(87 / 88-85 / 86)$ & $\Delta(89 / 90-87 / 88)$ \\
\hline Double-differences ${ }^{\mathrm{a}}$ unadjusted & $\begin{array}{c}.078 \\
(.027)\end{array}$ & $\begin{array}{l}-.092 \\
(.030)\end{array}$ & $\begin{array}{c}.012 \\
(.028)\end{array}$ \\
\hline Specification 1 & $\begin{array}{c}.050 \\
(.022)\end{array}$ & $\begin{array}{l}-.060 \\
(.024)\end{array}$ & $\begin{array}{c}.021 \\
(.023)\end{array}$ \\
\hline Specification 2 & $\begin{array}{c}.043 \\
(.022)\end{array}$ & $\begin{array}{l}-.060 \\
(.025)\end{array}$ & $\begin{array}{c}.021 \\
(.023)\end{array}$ \\
\hline Specification 3 & $\begin{array}{c}.013 \\
(.024)\end{array}$ & $\begin{array}{l}-.050 \\
(.026)\end{array}$ & $\begin{array}{c}.029 \\
(.024)\end{array}$ \\
\hline Triple-differences ${ }^{\mathrm{b}}$ unadjusted & $\begin{array}{c}.111 \\
(.045)\end{array}$ & $\begin{array}{l}-.240 \\
(.050)\end{array}$ & $\begin{array}{c}.123 \\
(.051)\end{array}$ \\
\hline Specification 1 & $\begin{array}{c}.076 \\
(.037)\end{array}$ & $\begin{array}{l}-.208 \\
(.041)\end{array}$ & $\begin{array}{c}.160 \\
(.041)\end{array}$ \\
\hline Specification 2 & $\begin{array}{c}.058 \\
(.036)\end{array}$ & $\begin{array}{l}-.208 \\
(.041)\end{array}$ & $\begin{array}{c}.151 \\
(.041)\end{array}$ \\
\hline Specification 3 & $\begin{array}{c}.078 \\
(.036)\end{array}$ & $\begin{array}{l}-.214 \\
(.040)\end{array}$ & $\begin{array}{c}.171 \\
(.041)\end{array}$ \\
\hline Specification 4 & $\begin{array}{c}.064 \\
(.036)\end{array}$ & $\begin{array}{l}-.213 \\
(.041)\end{array}$ & $\begin{array}{c}.167 \\
(.041)\end{array}$ \\
\hline Specification 5 & $\begin{array}{c}.048 \\
(.036) \\
\end{array}$ & $\begin{array}{l}-.223 \\
(.041) \\
\end{array}$ & $\begin{array}{c}.168 \\
(.041) \\
\end{array}$ \\
\hline
\end{tabular}

${ }^{\text {a }}$ The regression specifications correspond to the regressions presented in Table 3.

${ }^{b}$ The regression specifications correspond to the regressions presented in Table 4. 
implemented follows pre-IRCA increases in the relative wages of nonagricultural Latinos and is followed by a period of stable intersectoral wage differentials.

One qualification to the interpretation of these results concerns the possibility that our analysis only captures a short-term employer-sanctions effect. Several factors suggest that the long-term impact may be smaller than, or exceed, the short-term effects measured here. For example, Latino workers may not be affected by IRCA-induced discrimination until they change jobs. Given that workers hired before November 1986 are not subject to the verification and sanctions laws, employers have no incentive to discriminate against long-term employees who either are, or are suspected of being, undocumented. To the extent that this is the case, the full impact of employer sanctions may not be realized until all pre-IRCA employment matches involving Latino workers dissolve.

On the other hand, given the widespread availability of fraudulent documents after enactment of IRCA (GAO 1990), employer sanctions may have lost their bite in the long term. Employers are only required to make a good faith effort to check documents and are not responsible for verifying the authenticity of what is presented by employees. Although these potential long-term effects surely are important, the fact that our control group disappears with the 1988 imposition of sanctions limits the ability of the current methodological approach to assess these longer-term consequences.

Despite this qualification, the short-term negative wage effects discussed above are not negligible and hence deserve further attention. To the extent that these shifts are permanent, immigration reform may be contributing to inter-ethnic earnings differences that were already quite large. 
APPENDIX TABLE 1

Percentage of Latinos Born in United States and Percentage of Latinos Who Are Not U.S. Citizens, by Latino Ethnic Subgroup Identification

$\%$ Born in U.S. ${ }^{a}$

$\%$ Not U.S. Citizens

All Latinos

45.6

41.2

Mexican American

87.2

7.0

Chicano

91.7

1.9

Mexicano

14.7

71.5

Puerto Rican

92.3

0.0

Cuban

17.1

41.3

Central/South American

9.3

70.9

Other Spanish

63.0

25.9

Notes: Calculated from the February 1994 CPS. The sample includes all Latino wage and salary workers aged 16 to 65 .

${ }^{a}$ Includes all workers born in the U.S., Puerto Rico, and U.S. outlying areas. 


\section{APPENDIX TABLE 2}

Unweighted Double-Difference and Triple-Difference Estimates of Change in Relative Earnings of Latino Nonagricultural Workers, All Workers and by Gender

\begin{tabular}{|c|c|c|c|}
\hline & All Workers & Male & Female \\
\hline Double-differences ${ }^{\mathrm{a}}$ unadjusted & $\begin{array}{l}-.074 \\
(.033)\end{array}$ & $\begin{array}{l}-.088 \\
(.035)\end{array}$ & $\begin{array}{l}-.004 \\
(.089)\end{array}$ \\
\hline Specification 1 & $\begin{array}{l}-.043 \\
(.027)\end{array}$ & $\begin{array}{l}-.074 \\
(.029)\end{array}$ & $\begin{array}{c}.057 \\
(.075)\end{array}$ \\
\hline Specification 2 & $\begin{array}{l}-.050 \\
(.027)\end{array}$ & $\begin{array}{l}-.073 \\
(.029)\end{array}$ & $\begin{array}{c}.109 \\
(.080)\end{array}$ \\
\hline Specification 3 & $\begin{array}{l}-.042 \\
(.028)\end{array}$ & $\begin{array}{l}-.057 \\
(.030)\end{array}$ & $\begin{array}{c}.109 \\
(.081)\end{array}$ \\
\hline Triple-differences ${ }^{\mathrm{b}}$ unadjusted & $\begin{array}{l}-.176 \\
(.056)\end{array}$ & $\begin{array}{l}-.123 \\
(.062)\end{array}$ & $\begin{array}{l}-.258 \\
(.121)\end{array}$ \\
\hline Specification 1 & $\begin{array}{l}-.160 \\
(.045)\end{array}$ & $\begin{array}{l}-.141 \\
(.050)\end{array}$ & $\begin{array}{l}-.207 \\
(.103)\end{array}$ \\
\hline Specification 2 & $\begin{array}{l}-.161 \\
(.045)\end{array}$ & $\begin{array}{l}-.126 \\
(.050)\end{array}$ & $\begin{array}{l}-.182 \\
(.104)\end{array}$ \\
\hline Specification 3 & $\begin{array}{l}-.167 \\
(.044)\end{array}$ & $\begin{array}{l}-.143 \\
(.049)\end{array}$ & $\begin{array}{l}-.202 \\
(.102)\end{array}$ \\
\hline Specification 4 & $\begin{array}{l}-.167 \\
(.045)\end{array}$ & $\begin{array}{l}-.128 \\
(.049)\end{array}$ & $\begin{array}{l}-.178 \\
(.103)\end{array}$ \\
\hline Specification 5 & $\begin{array}{l}-.177 \\
(.045)\end{array}$ & $\begin{array}{l}-.136 \\
(.050)\end{array}$ & $\begin{array}{l}-.188 \\
(.103)\end{array}$ \\
\hline
\end{tabular}

${ }^{a}$ The regression specifications correspond to the regressions presented in Table 3.

${ }^{b}$ The regression specifications correspond to the regressions presented in Table 4. 


\section{APPENDIX TABLE 3}

Unadjusted Double-Difference and Triple-Difference Estimates of Effects of Employer Sanctions Using Alternative Single-Year Time Periods, All Workers Only

\begin{tabular}{|c|c|c|c|c|c|c|c|}
\hline & \multicolumn{3}{|c|}{ Latino } & \multicolumn{3}{|c|}{ Non-Latino White } & \multirow[b]{2}{*}{$\Delta^{3}$} \\
\hline & NonAg & $\mathrm{Ag}$ & $\Delta($ Non $\mathrm{Ag}-\mathrm{Ag})$ & NonAg & $\mathrm{Ag}$ & $\Delta(\operatorname{Non} A g-A g)$ & \\
\hline 1986 & $\begin{array}{l}1.797 \\
(.007)\end{array}$ & $\begin{array}{l}1.329 \\
(.033)\end{array}$ & $\begin{array}{c}.468 \\
(.031)\end{array}$ & $\begin{array}{c}2.147 \\
(.004)\end{array}$ & $\begin{array}{l}1.759 \\
(.037)\end{array}$ & $\begin{array}{c}.388 \\
(.037)\end{array}$ & - \\
\hline 1987 & $\begin{array}{l}1.781 \\
(.007)\end{array}$ & $\begin{array}{l}1.421 \\
(.023)\end{array}$ & $\begin{array}{c}.360 \\
(.030)\end{array}$ & $\begin{array}{c}2.137 \\
(.004)\end{array}$ & $\begin{array}{l}1.677 \\
(.041)\end{array}$ & $\begin{array}{c}.460 \\
(.042)\end{array}$ & - \\
\hline$\Delta$ (Post-Pre) & $\begin{array}{l}-.016 \\
(.010)\end{array}$ & $\begin{array}{c}.092 \\
(.039)\end{array}$ & $\begin{array}{l}-.108 \\
(.042)\end{array}$ & $\begin{array}{l}-.010 \\
(.006)\end{array}$ & $\begin{array}{l}-.082 \\
(.055)\end{array}$ & $\begin{array}{c}.072 \\
(.056)\end{array}$ & $\begin{array}{c}-.180 \\
(.070)\end{array}$ \\
\hline 1986 & $\begin{array}{l}1.797 \\
(.007)\end{array}$ & $\begin{array}{l}1.329 \\
(.033)\end{array}$ & $\begin{array}{c}.468 \\
(.031)\end{array}$ & $\begin{array}{c}2.147 \\
(.004)\end{array}$ & $\begin{array}{l}1.759 \\
(.037)\end{array}$ & $\begin{array}{c}.388 \\
(.037)\end{array}$ & - \\
\hline 1988 & $\begin{array}{l}1.764 \\
(.008)\end{array}$ & $\begin{array}{l}1.443 \\
(.021)\end{array}$ & $\begin{array}{c}.321 \\
(.031)\end{array}$ & $\begin{array}{c}2.138 \\
(.005)\end{array}$ & $\begin{array}{l}1.521 \\
(.043)\end{array}$ & $\begin{array}{c}.617 \\
(.044)\end{array}$ & - \\
\hline$\Delta$ (Post-Pre) & $\begin{array}{l}-.033 \\
(.011)\end{array}$ & $\begin{array}{c}.114 \\
(.038)\end{array}$ & $\begin{array}{l}-.147 \\
(.044)\end{array}$ & $\begin{array}{l}-.009 \\
(.006)\end{array}$ & $\begin{array}{l}-.238 \\
(.056)\end{array}$ & $\begin{array}{c}.229 \\
(.057)\end{array}$ & $\begin{array}{l}-.376 \\
(.072)\end{array}$ \\
\hline 1985 & $\begin{array}{l}1.796 \\
(.007)\end{array}$ & $\begin{array}{l}1.399 \\
(.022)\end{array}$ & $\begin{array}{c}.397 \\
(.028)\end{array}$ & $\begin{array}{c}2.128 \\
(.004)\end{array}$ & $\begin{array}{l}1.731 \\
(.037)\end{array}$ & $\begin{array}{c}.398 \\
(.037)\end{array}$ & - \\
\hline 1987 & $\begin{array}{l}1.781 \\
(.007)\end{array}$ & $\begin{array}{l}1.421 \\
(.023)\end{array}$ & $\begin{array}{c}.360 \\
(.030)\end{array}$ & $\begin{array}{c}2.137 \\
(.004)\end{array}$ & $\begin{array}{l}1.677 \\
(.041)\end{array}$ & $\begin{array}{c}.460 \\
(.042)\end{array}$ & - \\
\hline$\Delta$ (Post-Pre) & $\begin{array}{l}-.015 \\
(.010)\end{array}$ & $\begin{array}{c}.022 \\
(.032)\end{array}$ & $\begin{array}{l}-.037 \\
(.041)\end{array}$ & $\begin{array}{c}.008 \\
(.006)\end{array}$ & $\begin{array}{l}-.054 \\
(.055)\end{array}$ & $\begin{array}{c}.062 \\
(.055)\end{array}$ & $\begin{array}{c}-.099 \\
(.069)\end{array}$ \\
\hline
\end{tabular}




\section{APPENDIX TABLE 3, continued}

\begin{tabular}{|c|c|c|c|c|c|c|c|}
\hline & \multicolumn{3}{|c|}{ Latino } & \multicolumn{3}{|c|}{ Non-Latino White } & \multirow[b]{2}{*}{$\Delta^{3}$} \\
\hline & NonAg & $\mathrm{Ag}$ & $\Delta($ NonAg-Ag) & NonAg & $\mathrm{Ag}$ & $\Delta($ Non $A g-A g)$ & \\
\hline 1985 & $\begin{array}{l}1.796 \\
(.007)\end{array}$ & $\begin{array}{l}1.399 \\
(.022)\end{array}$ & $\begin{array}{c}.397 \\
(.028)\end{array}$ & $\begin{array}{l}2.128 \\
(.005)\end{array}$ & $\begin{array}{l}1.731 \\
(.037)\end{array}$ & $\begin{array}{c}.398 \\
(.037)\end{array}$ & - \\
\hline 1988 & $\begin{array}{l}1.764 \\
(.008)\end{array}$ & $\begin{array}{l}1.443 \\
(.021)\end{array}$ & $\begin{array}{c}.321 \\
(.031)\end{array}$ & $\begin{array}{l}2.138 \\
(.005)\end{array}$ & $\begin{array}{l}1.521 \\
(.043)\end{array}$ & $\begin{array}{c}.617 \\
(.044)\end{array}$ & - \\
\hline$\Delta$ (Post-Pre) & $\begin{array}{l}-.032 \\
(.010) \\
\end{array}$ & $\begin{array}{c}.044 \\
(.031) \\
\end{array}$ & $\begin{array}{l}-.076 \\
(.041) \\
\end{array}$ & $\begin{array}{c}.010 \\
(.006) \\
\end{array}$ & $\begin{array}{l}-.209 \\
(.057) \\
\end{array}$ & $\begin{array}{c}.219 \\
(.056) \\
\end{array}$ & $\begin{array}{r}-.295 \\
(.071) \\
\end{array}$ \\
\hline
\end{tabular}




\section{References}

Black, Dan A. 1995. "Discrimination in an Equilibrium Search Model." Journal of Labor Economics 13: 309-334.

Borjas, George J. 1994. “The Economics of Immigration.” Journal of Economic Literature 32: 1667-1717.

Card, David E., and Alan B. Krueger. 1995. Myth and Measurement: The New Economics of the Minimum Wage. Princeton, NJ: Princeton University Press.

DiNardo, John, Nicole M. Fortin, and Thomas Lemieux. 1996. "Labor Market Institutions and the Distribution of Wages, 1973-1992” Econometrica 64: 1001-1044.

Donato, Katharine M., Jorge Durand, and Douglas S. Massey. 1992. "Changing Conditions in the U.S. Labor Market: Effects of the Immigration Reform and Control Act of 1986." Population Research and Policy Review 11: 93-115.

Donato, Katharine M., and Douglas S. Massey. 1993. "Effect of the Immigration Reform and Control Act on the Wages of Mexican Migrants." Social Science Quarterly 74: 523-541.

Freeman, Richard B., and Lawrence F. Katz. 1994. "Rising Wage Inequality: The United States vs. Other Advanced Countries." In Working under Different Rules, edited by Richard B. Freeman. New York: Russell Sage Foundation, pp. 29-62.

General Accounting Office (GAO). 1990. Immigration Reform: Employer Sanctions and the Question of Discrimination. Report \# GGD 90-62.

Hamermesh, Daniel, and Stephen J. Trejo. 1998. "The Demand for Hours of Labor: Direct Evidence from California." Unpublished manuscript.

Humel-Montwieler, Nancy. 1987. The Immigration Reform Law of 1986: Analysis, Text, and Legislative History. Washington, DC: Bureau of National Affairs.

Keeley, Charles B. 1993. "The United States of America: Retaining a Fair Immigration Policy.” In The Politics of Migrations Policies: Settlement and Integration the First World into the 1990s, edited by Daniel Kubat. New York: Center For Migration Studies, pp. 60-84.

Kenney, Genevieve M., and Douglas A. Wissoker. 1994. "An Analysis of the Correlates of Discrimination Facing Young Hispanic Job-Seekers.” American Economic Review 84: 674-683.

Kubat, Daniel. 1993. “Canada: Immigration's Humanitarian Challenge.” In The Politics of Migrations Policies: Settlement and Integration the First World into the 1990s, edited by Daniel Kubat. New York: Center for Migration Studies, pp. 23-44. 
Levy, Frank, and Richard Murnane. 1992. "U.S. Earnings Levels and Earnings Inequality: A Review of Recent Trends and Proposed Explanations.” Journal of Economic Literature 30: 1333-1382.

Lowell, B. Lindsay, Jay Teachman, and Zhongren Jing. 1995. "Unintended Consequences of Immigration Reform: Discrimination and Hispanic Employment." Demography 32: 617-628.

Martin, Philip L., and J. Edward Taylor. 1988. "Harvest of Confusion: SAWs, RAWs, and Farmworkers." Working Paper PRIP-UI-4, Urban Institute.

Martin, Philip L., and J. Edward Taylor. 1990. "The Initial Effects of Immigration Reform on Farm Labor in California." Population Research and Policy Review 9: 255-283.

Miller, Mark J. 1994. “Towards Understanding State Capacity to Prevent Unwanted Immigration: Employer Sanctions Enforcement in France, 1975-1990." West European Politics 17(2): 141-169.

Morita, Kiriro, and Saskia Sassen. 1994. "The New Illegal Immigration in Japan, 1980-1992." International Migration Review 28(1): 153-163.

Perotti, Rosanna. 1994. "Employer Sanctions and the Limits of Negotiation." Annals of the American Academy of Political and Social Science 534: 31-43.

Phillips, Julie A., and Douglas S. Massey. 1998. "The New Labor Market: Immigrants and Wages After IRCA.” Unpublished manuscript, Population Studies Center, University of Pennsylvania.

Raphael, Steven, and David A. Riker. 1998. "Geographic Mobility, Race, and Wage Differentials." Journal of Urban Economics, forthcoming.

Sorensen, Elaine, and Frank D. Bean. 1994. "The Immigration Reform and Control Act and the Wages of Mexican Origin Workers: Evidence from Current Population Surveys.” Social Science Quarterly 75: $1-17$.

U.S. Immigration and Naturalization Service (INS). 1990. 1989 Statistical Yearbook of the Immigration and Naturalization Service. Washington, DC: U.S. Government Printing Office.

U.S. Immigration and Naturalization Service (INS). 1991. 1990 Statistical Yearbook of the Immigration and Naturalization Service. Washington, DC: U.S. Government Printing Office.

Woodrow, Karen A., and Jeffrey S. Passel. 1990. "Post-IRCA Undocumented Immigration to the United States: An Assessment Based on the June 1988 CPS." In Undocumented Migration to the United States: IRCA and the Experience of the 1980s, edited by Frank D. Bean, Barry Edmonston, and Jeffrey S. Passel. Washington, DC: Urban Institute Press. 